\title{
The Rationale for Responsible Supply Chain Management and Stakeholder Engagement
}

\author{
Mark Anthony Camilleri ${ }^{1}$, University of Malta, Malta and University of \\ Edinburgh, Scotland.
}

This paper was accepted for publication by the Journal of Global Responsibility (An Emerald Journal)

\begin{abstract}
Purpose

Firms are increasingly resorting to responsible supply chain management as they align their economic success with socially-responsible initiatives in their value chain. This contribution suggests that there are opportunities for global corporations who are keen on integrating responsible practices into their business operations. It is in their interest to report about their responsible supply chain management, social performance and sustainable innovations to their stakeholders.
\end{abstract}

\section{Design/methodology/approach}

This review paper identifies future research avenues in the promising areas of responsible procurement and global supply chain management.

\section{Findings}

The corporations' differentiated strategies as well as their proactive engagement in responsible supply chain management can lead them to achieve a competitive advantage in the long term. the low-cost producers may be neglecting the marketplace stakeholders, including suppliers, distributors among others. Moreover, the smaller businesses' could not be in a position to follow responsible procurement practices as they may lack the scarce resources to do so.

\section{Originality/value}

This paper raises awareness about the integration of socially responsible behaviours and sustainable practices in business operations. It contends that a responsible supply chain management necessitates an improved relationship with suppliers and distributors in the value chain. This stakeholder engagement with ultimately create value to the businesses themselves.

Keywords: Supply Chain Management, Responsible Supply Chain Management, Responsible Procurement, Corporate Reputation, Stakeholder Management.

\footnotetext{
${ }^{1}$ Affiliation Details: Mark Anthony Camilleri, Resident Academic Lecturer, Department of Corporate Communication, Faculty of Media and Knowledge Sciences, University of Malta, Msida, MSD2080, Malta.
} 


\section{Introduction}

The globalised supply chain is strongly shaping both the production and the consumption of products in different markets as the international markets have been (or are being) liberalised and deregulated. In this light, very often businesses source their materials or products from developing and / or transitioning countries in order to reduce their production and distribution costs. Consequentially, there may be perceived shortcomings in the companies' procurement of materials and products as well as in their supply chain's regulatory capacity. At the same time, many stakeholders including consumers are increasingly inquiring on the regulation of unwanted economic, social and environmental side-effects of low-cost production. This is a globalisation phenomenon that has triggered new views on the firms' responsible supply chain management and genuine stakeholder engagement (Gold and Heikkurinen, 2013),

The multi-national brands that are usually based in the developed world play a central role in the organisation of global supply chains. Big companies focus on activities such as product design, marketing and brand management in their home country. However, they may decide to outsource their operations in low-income countries. The third world countries' suppliers are often accused for their social and environmental deficits as they are pressurised to enhance their productivity levels. Of course, their irresponsible behaviours toward employees and their surrounding environment could negatively affect their competitiveness in the long term. Unfair employment conditions and work practices are very likely to occur in industries where production is labour intensive and where the automation is limited. Notwithstanding, there are increasing competitive pressures to lower production costs by using subcontractors. This way, the big brands could not control the lower echelons in their production chain.

This paper provides a comprehensive review of contributions on the responsible supply chain management. It also explains how firms use responsible procurement and supply chain management to protect and enhance their corporate reputation. This contribution takes into account a wide range of issues; including the stakeholder and legitimacy theories (Sarkis, Zhu and Lai, 2011; Donaldson and Preston, 1995), Hence, it discusses about the regulatory forces on labour market issues and describes the changing roles of consumers, industry peers and media in their endeavour to safeguard socially responsible and sustainable practices in the supply chain. 


\section{The Procurement of Materials and Products from the Global Supply Chain}

There has been a wide array of contributions on supply chain management from a variety of fields, including marketing (Closs, Speier and Meacham, 2011; Piercy and Lane, 2009), supply chain (Awaysheh and Klassen, 2010; Simpson, Power and Samson, 2007) and industrial marketing (Liu, Kasturiratne and Moizer, 2012; Ewing, Windisch, and Newton, 2010; Helm and Salminen, 2010), A thorough literature review suggests that academia have often conducted case-based studies that focused on the social performance of suppliers (Hoejmose, Brammer and Millington, 2013; Egels-Zanden, 2007), Others reported on the consequences of irresponsible social practices on customers (Phillips and Caldwell, 2005), It may appear that the recent research is concerned with the processes through which buyers manage social issues in the supply chain, rather than focusing on the social performance of suppliers (Hoejmose et al., 2013; Klassen and Vereecke, 2012; Awaysheh and Klassen, 2010), The "process" literature has provided considerable insights on the role of social management capabilities, including; monitoring, collaboration and innovation (Klassen and Vereecke, 2012); internal and external barriers and enablers (Walker and Jones, 2012); supply chain structures, namely; transparency, dependency and distance - for the adoption of socially responsible practices (Awaysheh and Klassen, 2010); inter-organisational resources as a 'collaborative paradigm' in supply chain management (Gold, Seuring and Beske, 2010) and third-party certification standards (Ciliberti, de Groot, de Haan, and Pontrandolfo, 2009) among other perspectives.

Other authors have investigated the impact of institutional factors on the adoption of socially responsible supply chain practices (Park-Poaps and Rees, 2010), Recent studies suggest that responsible supply chain management should be related with the firm's strategy as it leads to significant outcomes, including; improved relationships with stakeholders as well as reputational benefits (Yawar and Seuring, 2015; Monczka, Handfield, Giunipero and Patterson, 2015; Hoejmose et al., 2013; Carter and Rogers, 2008; Seuring and Müller, 2008; Sirsly and Lamertz, 2008; McElhaney, 2009; McManus, 2008),

\section{The Responsible Supply Chain Management}

Firms are often facing increased stringent government regulations on their supply chain (Xia, $\mathrm{Zu}$ and Shi, 2015), Arguably, there are a number of governments hailing from the most 
advanced economies that have already redefined their conceptions of responsibility beyond their own national borders. However, the poorest countries may not possess the same legal frameworks and regulatory policies on responsible supply chain management. Even if they have policies, guiding principles and codes of conducts in place; they will not necessarily enforce them in their workplace environments. For instance, in 2013; there were more than 1,100 victims when a building collapsed on the factory workers in Bangladesh. This tragic case has raised awareness about responsible procurement from global supply chains. As a result, many stakeholders have become more concerned about the responsible sourcing of materials and products (Gold and Heikkurinen, 2013), Non-governmental organisations (NGOs) and customers themselves are constantly demanding for an increased focus on corporate responsibility practices in the value chain. This is especially the case for brandowning companies, as they are likely to come under pressure from diverse stakeholders, including NGOs.

The bigger companies are expected to consider their environmental and social responsibility across their entire supply chain. The stakeholder pressures are often being manifested both in conflict (e.g. name-and-shame campaigns and consumer 'boycotts' targeting big brands) and in the pro-active developments of multiple institutional and regulatory innovations toward 'sustainable supply chain management', including; eco-labelling, codes of conduct, auditing procedures, product information systems, procurement guidelines and eco-branding. Therefore, the purchasing and supply chain managers of the global brands are increasingly recognising the importance of integrating social and environmental responsibility in their day-to-day operations. Some businesses are also embedding certain NGOs' standards (e.g., ISO 14001 and ISO 26000) in their daily tasks. Such triggers have increased corporate interest in fair trading, environmental management and responsible supply chain management.

The responsible supply chain management is an issue affecting the businesses' production, supply and distribution of materials. In the past, many big corporations including; Adidas, Benetton, BP, CandA, Disney, Levi Strauss, Nike and Primark among others have been blamed for their irresponsible or unethical behaviours (Jones, Temperley and Anderson, 2009; Winstanley, Clark and Leeson, 2002), Very often, these companies' suppliers or distributors were based in third world countries; where they offered inhumane conditions for employees in their work place environments (Hemphill and Kelley, 2016), Alternatively, 
these businesses were accused of contaminating the (local) natural environment. Their irresponsible behaviours often translated to a tarnished corporate images and significant losses in revenue. Notwithstanding, it is not only the business-to-consumer firms that have experienced such reputational damage. At times, the business-to-business market has also experienced negative publicity due to poor supply chain practices (Lefevre, Pellé, Abedi, Martinez, and Thaler, 2010); although such businesses could be better placed to put pressure on suppliers to take their responsible behaviours more seriously (Sharma, Gopalkrishnan, Mehrotra, and Krishnana, 2010), Such contentious issues have led several customers, including businesses to become increasingly wary of the social and environmental impact of their purchases. Moreover, many consumer groups and NGOs have often set their agenda toward a socially responsible transition. Many campaigns are raising awareness on organically-grown foods, anti-sweatshop labour codes, fair trading as they promote locally produced goods.

Xia et al. (2015) indicated that stringent government rules could drive firms to proactively improve their responsible supply chain performance. Historically, firms were often deemed reactive in their corporate social responsibility (CSR) engagement. It may appear that the notion of proactivity in this context is a recent phenomenon. Very often, the businesses may be more concerned on their legislative compliance than on their genuine commitment to embedding responsible procurement practices at the firm level (Preuss, 2001), In this light, in 1997, President Clinton had initiated the Apparel Industry Partnership which involved the introduction of a code of conduct and relevant principles that were intended to monitor operational activities in work place environments. Evidently, the US president has responded to the numerous stakeholder pressures regarding unfair labour conditions in the U.S. supply chain. Since then, many corporations have adopted voluntary codes and engaged in various social initiatives such as monitoring systems and/or vendor certification requirements.

Other parties, such as media and independent NGOs, including the Fair Labor Association and Social Accountability's SA 8000 in the U.S. and the Ethical Trading Initiative in the UK, among others also played an important role in improving the responsible supply chain performance in different contexts. In particular, they were critical to the monitoring of any social transgressions and for informing and educating consumers about the global production and supply environments (Park-Poaps and Rees, 2010; Roberts, 2003), 
In the last few decades, several companies are increasingly taking social and sustainable performance into account when selecting their suppliers. For instance, Wal-Mart has created a global sustainability index in 2009. This index rates products according to their environmental and societal impacts of their manufacturing and distribution. Generally, responsible supply chain management is being quantified by using ratings that incorporate; social, ethical, cultural, and health footprints (also known as SECH ratings),

Interestingly, President Obama has endorsed the US Dodd-Frank Wall Street Reform and Consumer Protection Act in 2010. This act contained a supply chain sustainability provision in the form of a Conflict Minerals law. In a nutshell, this law requires SEC-regulated companies to conduct third party audits on their supply chains in order to determine whether they were procuring conflict minerals (including; tin, tantalum, tungsten or gold) from the Democratic Republic of the Congo. The SEC-regulated firms were mandated to create a report detailing their due diligence efforts as well as the results of their audits (which ought to be disclosed to the general public and SEC) The chain of suppliers and vendors of these reporting companies are expected to provide appropriate supporting information to their stakeholders.

In a similar vein, the state of California passed legislation that became effective as of the $1^{\text {st }}$ January, 2012 This bill mandated that the Californian retailers and manufacturers (who generated more than $\$ 100,000,000$ in annual worldwide gross receipts) to disclose their nonfinancial reporting (in terms of social and environmental performance), These entities are expected to report (in their annual corporate statements) how they are eradicating slavery and human trafficking from their direct supply chains for tangible goods offered for sale (Hemphill and Kelley, 2016; Pickles and Zhu 2013),

\section{Engaging with Responsible Suppliers}

The supply chain management is influenced by different stakeholders that may be considered as the "consumers" of businesses. Therefore, it is important to identify both primary and secondary stakeholders (Maignan, Ferrell and Ferrell, 2005), Businesses are increasingly realising that customers, competitors, regulators, agencies, media, suppliers and nongovernmental organisations (NGOs) are their primary stakeholders of socially responsible corporate behaviours (Buysse and Verbeke, 2003; Freeman and Reed, 1983), For this reason, there is scope in forging strategic buyer-supplier relationships as they rely on each other for 
their individual success (Gray and Balmer, 1998; Mohr and Spekman, 1994), Hence, the firms' proactive stance on the responsible supply chain management (in conjunction with their stakeholders) will help them enhance their reputation as they promote fair practices in the labour market. At the same time, it is in their interest to protect the natural environment throughout their distributive value chain.

According to the stakeholder theory, businesses are responsible toward various stakeholders as they are expected to respond to their different claims as an attempt to legitimise their existence (Park-Poaps and Rees, 2010; Freeman, 1999), Firms tend to favour those stakeholders who are powerful and important to them (Freeman, 1999), They must not only identify who their stakeholders are, but also determine whether their stakeholders' claims are manageable, considering the firm's limited and scarce resources. Their socially responsible supply chain orientation consists of both internal organisational direction as well as external partnerships. In their study in the apparel industry, Park-Poaps and Rees (2010) indicated that consumer and industry peer pressures were significantly related to the companies' internal direction, whilst the industry peers and media were significantly related to their external partnerships. Curiously, they found that regulation was not significantly related to either internal direction or external partnerships. Relevant studies have reported that such initiatives to control labour issues are still somewhat inefficient and ineffective due to hierarchal communication approaches (Fawcett and Magnan, 2002),

Other scholars have suggested that socially responsible initiatives require incorporating values of fair labour into the organisational core (Andersen and Skjoett-Larsen, 2009; Howard-Grenville and Hoffman, 2003), Very often, commentators argued that the development of partnerships among stakeholders could facilitate both internal and external communication, including; mutual understanding and cooperation on labour issues (Lim and Phillips, 2008), Therefore, the stakeholder engagement is expected to affect the lower levels in the supply chain (Park-Poaps and Rees, 2010), The socially responsible supply chain performance will ultimately influence stakeholder management, corporate image, consumer choices and reputation (Tate, Ellram and Kirchoff, 2010),

Given the development of today's stakeholders' expectations and demands, the contemporary subject of responsible behaviour is becoming an important instrument for the enhancement of corporate reputation (Fan, 2005; Caruana, 1997; Fombrun and Shanley, 1990), As businesses 
are socially responsible they minimise their risk and improve their stakeholder relations (Husted and Allen, 2001), In a similar vein, Fombrun and Shanley (1990) argued that the businesses' social and environmental responsiveness will bring reputational benefits.

\section{The Responsible Supply Chain Management and its effect on Corporate Reputation}

Corporate reputation has often been defined as "a set of attributes ascribed to a firm, that is inferred from the firm's past actions" (Weigelt and Camerer, 1988, p. 443), Fombrun and Shanley (1990) argued that reputation "signals publics about how a firm's products, jobs, strategies and prospects compare to those of competing firms" (p. 233), The value of reputation has been subject to extensive research by many scholars (Fombrun, Gardberg and Sever, 2000; Caruana and Chircop, 2000; Caruana, 1997), Relevant theoretical underpinnings have indicated how reputation influences the stakeholders' perceptions (Money, Hillenbrand and Downing, 2011), the customers' choices and their purchase intentions (Keh and Xie, 2009; Siegel and Vitaliano, 2007; Mohr and Webb, 2005) Therefore, corporate reputation is related to corporate financial performance (Camilleri, 2012; Flanagan, O'Shaughnessy, and Palmer, 2011), Much of the work on corporate social-financial performance also implicitly assumes that this relationship is positive, because an improved reputation facilitates revenue and profit growth (Orlitzky et al., 2003; Surroca, Tribó and Waddock,. 2010),

Extant work suggests that reputation is important because it establishes credibility (Greyser, 1999; Herbig et al., 1994), The notion that reputation is related to credibility has also been noted in the wider corporate social (and environmental) responsibility literature. McWilliams and Siegel (2001) argued that building a reputation of 'responsibility' can signal an improved reputation (Husted and Allen, 2007; Brammer and Millington, 2005; McWilliams and Siegel, 2001; Fombrun and Shanley, 1990), Hence, responsible corporate behaviour "builds trust and enhances the firm's reputation, which in turn attracts customers, employees, suppliers and distributors, not to mention earning the public's goodwill" (Lantos, 2001, p. 606), In a similar vein, Lewis (2003) also held that responsible behaviours can establish trust and ultimately develop a company's reputation. Social and environmental activities not only can enhance the reputation of the firm, but also enhance the goodwill trust of stakeholders (Carlisle and Faulkner, 2005; Siltaoja, 2006), 
Therefore, corporate reputation is fundamentally a signal to stakeholders (Ponzi, Fombrun and Gardberg, 2011) and is particularly important in markets where there is imperfect information (Hoejmose et al., 2014.; Weigelt and Camerer, 1988), The market signals, including engagement in social and environmental issues could help to improve corporate image (McWilliams and Siegel, 2001; Bagnoli and Watts, 2003), Markley and Davis (2007) also noted that responsible behaviours could send positive market signals. Therefore, today's businesses are expected to implement responsible supply chain practices by their stakeholders. If they won't they run the risk of damaging their corporate reputation and image. Hence, there is scope for firms to implement socially and environmentally responsible practices in their supply chains (Ansett, 2007), Responsible supply chain management encapsulates social issues (e.g. child labour, working conditions, human rights et cetera) and / or environmental matters (e.g. environmental protection, waste management, recycling, reusing natural resources et cetera) (Hemphill and Kelley, 2016; Hoejmose et al., 2013; Carter and Rogers, 2008; Seuring and Muller, 2008), Such responsible behaviours shield the firms from negative media attention and consumer boycotts (Hoejmose et al., 2013), The companies' stronger engagement in socially responsible supply chain management enables them to manage exposure to risk (Tate et al, 2010; Van De Ven and Jeurissen, 2005), Thus, the businesses' stakeholder engagement and their responsible procurement of materials and products is linked to corporate reputation, which in turn allows them to target discerning customer groups (Phillips and Caldwell, 2005; Roberts, 2003),

Kleindorfer, Singhal, and Wassenhove (2005) suggested that responsible supply chain practices can lead to increased profitability, as customer satisfaction and loyalty will improve as a result of a stronger reputation. Conversely, the firms risk losing customers to rival companies if they fail to be responsible in their supply chain. In fact, Harwood and Humby (2008) findings suggested that suppliers were adhering to specific corporate social responsibility (CSR) requirements in order to reduce their exposure to risk. It may appear that ongoing CSR behaviours and environmental management protect the firms' reputation. This reflects Burke's (2011) argumentation as he suggested that the firms' positive actions including CSR programmes and the other tangible things enhance their corporate reputation.

Therefore, the distinction between reputation protection and enhancement is subtle, but important. Corporate reputation protection is concerned with evidencing the firms' efforts to meeting the stakeholders' expectations, whilst reputation enhancement goes beyond a purely 
evidential basis which encompasses embedded practice. Corporate reputation protection occurs when firms can prove to stakeholders that they took reasonable steps to prevent certain incidents from happening (Coombs, 2014), In fact, corporate reputations could be jeopardised by irresponsible supply chain practices which may "directly harm business contracts, marketing and sub-sourcing, and damage the corporation's brands and the trust they have established with their business customers" (Lee and Kim, 2009, p. 144), The companies' failure to manage their supply chain in a responsible manner could result in negative repercussions for their bottom line. Conversely, the corporations' reputation and credentials in socially responsible supply chain management could lead them to achieve a competitive advantage in the long term (Ansett, 2007; McWilliams et al., 2006),

\section{The link between Responsible Supply Chain Management and a Differentiated Strategy}

Firms should seek to "have their reputation stand out from their group" (Ferguson et al., 2000 , p. 1211) in order to increase their chances of building a competitive advantage (Porter, 1986; Porter and Kramer, 2006), Consequently, an improved corporate reputation may be considered as an important lever for the businesses' long term prospects. A growing body of literature has noted the relationship between supply chain practices and business strategy (McManus, 2008; Cousins, 2005; Fombrun and Shanley, 1990), Those firms that implement and develop responsible supply chain practices are clearly pursuing differentiation strategies (McWilliams and Siegel, 2001), Therefore, "the supply chain function cannot be viewed in isolation from the firm and its competitive advantage" (Knudsen, 2003, p. 720; Watts et al., 1995), This suggests that the organisational goals could guide the supply chain practices (Power, 2005), and that the two variables must be coordinated (Tamas, 2000), Narasimhan and Carter (1998) argued that the supply chain strategy must support product and market characteristics, for firms to achieve a competitive advantage. They held that those firms, who adopted a differentiation / customisation strategy were choosing those suppliers who were characterised for their product innovation, technological leadership, total quality management and internal organisational integration.

In contrast, they contended that the firms that pursued traditional manufacturing-oriented strategies (low-cost) prioritised on rapid volume change, fast delivery, low prices and external organisational integration. The low-cost firms generally consider the role of the supply chain function to be one of cost reduction, whereas the firms pursuing differentiation 
strategies view supply chain management as a central function for them (Narasimhan and Carter, 1998), The low cost firms are less likely to collaborate with suppliers on their shared responsibilities toward conflict resolution (Park and Dickson, 2008, p. 52), At times, they may seek to exploit the labour market in search of lower prices (Park and Dickson, 2008), Such firms are unlikely to manage labour issues in their supply chain as this would increase their costs. Very often, low-cost retailers are being pressurised to lower their prices and to provide added value. For these reasons, they may frequently change suppliers and make them bid against one another. Therefore, the low cost suppliers may not be motivated to comply with the guiding principles and responsible codes of conduct (Hoejmose et al., 2013; Fearne, Duffy and Hornibrook, 2005), For instance, some of the major low-cost retailers regularly exploit other businesses as they may have bargaining power over their suppliers. They may force them to bear cost increases in the supply chain.

Under such circumstances, the low-cost firms often try to exploit all sources of cost advantage. They may not engage in socially responsible activities as this will result in higher discretionary costs for them. Very often, low-cost producers will neglect socially responsible supply chain management because it is costly for them and they do not consider CSR engagement as core to their business strategy (Hoejmose et al., 2013), Empirical evidence suggests that social responsibility is often neglected in low-cost sourcing contexts (Andersen and Skjoett-Larsen, 2009; Boyd, Spekman, Kamauff, and Werhane, 2007; Gugler and Shi, 2009), The stakeholder engagement (with suppliers) could be problematic for many businesses because they operate in highly competitive environments; where the focus is on price (Barrientos and Smith, 2007), In these cases, the firms that pursue low-cost strategies will inevitably neglect responsible behaviors in the value chain.

On the contrary, the firms that pursue differentiation strategies often engage with their suppliers These firm develop highly collaborative relationships and foster joint market strategies with them. The engagement with suppliers is stronger and deeper when the firms pursue differentiation strategies (Porter and Kramer, 2006), González-Benito (2007) found that the fit between business strategy and purchasing strategy significantly moderates the relationship between purchasing efficacy (as measured by the fit between purchasing strategy and capabilities, and firm performance), It may appear that focal firms invest in building relationships with suppliers in order to improve their effectiveness and to gain potential collaborative advantages (Hoejmose et al., 2013), Interestingly, Baier, Hartmann and Moser 
(2008) noticed that innovative firms were emphasising on supplier management, talent management, integration and core processes; as they compared them to low-cost firms that were more focused on information and knowledge management (rather than cross-functional collaboration), Very often, the low-cost producers consider the supply chain as a source of cost savings and invest less in supplier development (Hoejmose et al., 2013),

The firms that pursue differentiation strategies resort to socially responsible activities, along with other marketing activities, such as advertising as a signalling tool (McWilliams and Siegel, 2001), In a similar vein, Van De Ven and Jeurissen (2005) argued that firms that pursue differentiation strategies tend to engage more proactively with social responsibility, when compared to low-cost producers. They reasoned that the differentiation strategies of the socially responsible firms were improving their corporate image by signalling quality and trustworthiness (McWilliams and Siegel, 2001; Van De Ven and Jeurissen, 2005), Cruz and Boehe (2008) also noted that a responsible supply chain is increasingly being used as a differentiation strategy. They recognised that a successful organisational performance is dependent on the promotion of laudable activities and on raising awareness of the responsible procurement of materials and products, fair trading and respecting labour rights. Therefore, from a market-based perspective, social responsibility (and responsible supply chain management) can add value to the differentiated businesses.

Avram and Kahne (2008) argued that firms could charge a premium for their CSR-oriented approaches. The sustainable products' market positioning could be improved through the use of social responsibility and responsible supply chain management (Palazzo and Basu, 2007), There are positive implications for certain firms that pursue differentiation strategies (through social and environmentally responsible practices) as a means to signal an image of high product quality and sustainability to consumers (Tate et al, 2010), As a matter of fact, numerous findings reported how socially responsible business practices are actually improving both brand equity and organisational performance (Lai, Chiu, Yang, and Pai, 2010; Castaldo, Perrini, Misani and Tencati, 2009),

On the other hand, some other contributions have indicated that there is little evidence on socially responsible firms that pursue niche strategies in narrow markets (Van De Ven and Jeurissen, 2005; Weitzner and Darroch, 2010), It may appear that the supply chain literature has often ignored how niche firms develop their supply chain strategies (Baier et al., 2008; 
Cousins, 2005), Perhaps, it may prove difficult for academia to propose a specific relationship between niche strategy and socially responsible supply chain management. The responsible procurement of materials and products may not necessarily constitute a part of the firms' strategy. Notwithstanding, the promotion of the responsible supply chain management could be beneficial if it is directed toward socially conscious consumer groups (Weitzner andDarroch, 2010),

Weitzner and Darroch (2010) argued that there is a wide array of niche strategies that strive in their endeavours to appeal to different market subgroups. The specialised products that are marketed using a niche strategy will be easily distinguishable from other competitors' products. The niche strategies are often associated with relatively high cost structures (Galbraith and Schendel, 1983), with informal and reactive decision making processes (Miller and Toulouse, 1986), Debatably, the typical niche firms may not have the necessary resources to implement the responsible supply chain management practices, which often require time and expertise in terms of formal processes. The firms pursuing niche strategies, including; well-intended small and medium sized enterprises (SMEs) may find it difficult to manage their distributive chain. On paper, the inclusion of social and environmental requirements as preconditions to the supply of their materials and products would probably decrease the small businesses' motivation to engage in CSR. In fact, Baden, Harwood and Woodward (2009) reported that the SME owner managers were put off by the exhaustive formalities, whilst others thought that such responsible behavioural criteria would be counterproductive for them. Hence, the smaller firms (in particular) may encounter unique challenges if they decide to implement responsible supply chain management (Ciliberti et al., 2008; Russo and Perrini, 2010; Pedersen, 2009),

\section{Discussion and Conclusions}

Generally, firms are becoming more proactive in their engagement with responsible supply chain management and stakeholder engagement. Very often, corporate responsible behaviours could form part of their broader strategic commitment toward stakeholders (Zhu, Sarkis and Lai, 2013; Walker, Di Sisto and McBain, 2008; Walker and Preuss, 2008), This contribution is based on the premise that corporations could make a genuine and sustaining effort to align their economic success with corporate social responsibility in their value chain. 
The corporations' differentiated strategies as well as their proactive engagement in responsible supply chain practices can lead them to achieve a competitive advantage in the long term. In this case, firms may have sophisticated responsible procurement processes in place. Therefore, they could be in a better position to support their different suppliers. On the other hand, there could be low-cost producers that may be neglecting socially responsible supply chain management. In a similar vein, niche operators may not necessarily adopt responsible supply chain practices. Nevertheless, such firms tend to exhibit stronger ties with their suppliers; they may be relatively proactive vis-a-vis their socially responsible behaviours.

Previous studies indicated that there are significant gaps between policy and practice (Govindan, Kaliyan, Kannan and Haq 2014; Preuss, 2009; Yu, 2008; Egels-Zanden, 2007), For the time being; firms may (or may not) be inclined to implement responsible supply chain and manufacturing processes on a voluntary basis. However, the big businesses are increasingly becoming aware that they are susceptible to negative media exposure, stakeholder disenfranchisement, particularly if they are not responsible in their supplier relationships (or if their social and environmental policies are not fully-implemented),

Arguably, a differentiated strategy can serve as a powerful competitive tool in the global marketplace as the customers' awareness of social and responsibility rises. Notwithstanding, many stakeholders are increasingly becoming acquainted with fair trade and sustainability issues; as empowered consumers and lobby groups could enforce firms to invest in a more responsible supply chain.

Undoubtedly, there are opportunities for the proactive firms who are keen on integrating responsible practices into their business operations. It is in these firms' interest to report about their responsible supply chain management, social performance and sustainable innovations to their stakeholders. The corporations' environmental, social and governance disclosures will help them raise their profile in their value chain.

The responsible businesses can possibly achieve a competitive advantage as they build (and protect) their reputation with stakeholders. Of course, there are different contexts and social realities. The global supply chain and the international NGOs also play a critical role in the enforcement of responsible behaviours in the supply chain. 
In conclusion, this paper contended that the responsible supply chain management as well as forging stakeholder relationships with suppliers and distributors is a means to create value to the businesses themselves.

\section{Possible Research Avenues}

Future research could shed light on how businesses are communicating about how they are managing their responsible supply chains in collaboration with their different stakeholders. Alternatively, they may explore how multinational organisations are actively building relationships with governments and regulatory authorities to foster a safe working environment for their domestic labour market. Moreover, academia could investigate in detail about the procurement of sustainable products in different contexts. They could aggregate product characteristics (such as price, perceived quality, energy efficiency, convenience to repair, ease to recycle and reuse, et cetera) and explore their effect on the consumers' purchasing decisions. Researchers may investigate the consumer's ethical disposition to purchase sustainable products. These findings could also provide additional, meaningful data to the business practitioners as they may (not) be intrigued to invest in a responsible supply chain.

\section{References}

Andersen, M., and Skjoett-Larsen, T. (2009), "Corporate social responsibility in global supply chains", Supply Chain Management: An International Journal, Vol. 14 No. 2, pp. 7586.

Ansett, S. (2007), "Mind the Gap: A journey to sustainable supply chains", Employee Responsibilities and Rights Journal, Vol. 19 No. 4, pp. 295-303.

Awaysheh, A. and Klassen, R. D. (2010), "The impact of supply chain structure on the use of supplier socially responsible practices", International Journal of Operations and Production Management, Vol. 30 No. 12, pp. 1246-1268.

Avram, D. and Kahne, S. (2008), "Implementing responsible business behavior from a strategic management perspective: developing a framework for Austrian SMEs", Journal of Business Ethics, Vol. 82 No. 2, pp. 463-475. 
Baden, D. A., Harwood, I. A., and Woodward, D. G. (2009), "The effect of buyer pressure on suppliers in SMEs to demonstrate CSR practices: an added incentive or counter productive?" European Management Journal, Vol. 27 No 6, pp. 429-441.

Bagnoli, M., and Watts, S. G. (2003), "Selling to socially responsible consumers: Competition and the private provision of public goods", Journal of Economics and Management Strategy, Vol. 12 No. 3, pp. 419-445.

Baier, C., Hartmann, E., and Moser, R. (2008), "Strategic alignment and purchasing efficacy: an exploratory analysis of their impact on financial performance", Journal of Supply Chain Management, Vol. 44 No.4, pp 36-52.

Barrientos, S., and Smith, S. (2007), "Do workers benefit from ethical trade? Assessing codes of labour practice in global production systems", Third World Quarterly, Vol. 28 No. 4, pp. 713-729.

Boyd, D. E., Spekman, R. E., Kamauff, J. W., and Werhane, P. (2007), “Corporate social responsibility in global supply chains: A procedural justice perspective", Long Range Planning, Vol. 40 No. 3, pp. 341-356.

Brammer, S., and Millington, A. (2005), "Corporate reputation and philanthropy: An empirical analysis", Journal of business ethics, Vol. 61 No. 1, pp. 29-44.

Burke, R. J. (2011), “Corporate reputations: Development, maintenance, change and repair", Corporate reputation: Managing opportunities and threats, pp. 1-43.

Buysse, K., and Verbeke, A. (2003), "Proactive environmental strategies: A stakeholder management perspective", Strategic management journal, Vol. 24 No. 5, pp. 453-470.

Camilleri, M. A. (2012), “Creating shared value through strategic CSR in tourism”, PhD Thesis, Edinburgh Research Archive, University of Edinburgh, Edinburgh, UK https://www.era.lib.ed.ac.uk/handle/1842/6564

Carlisle, Y. M., and Faulkner, D. O. (2005), "The strategy of reputation", Strategic Change, Vol. 14 No. 8, pp. 413-422.

Caruana, A. (1997), "Corporate reputation: concept and measurement”, Journal of Product and Brand Management, Vol. 6, No. 2, pp. 109-118. 
Caruana, A., and Chircop, S. (2000), "Measuring corporate reputation: A case example", Corporate Reputation Review, Vol. 3 No. 1, pp. 43-57.

Carter, C. R., and Rogers, D. S. (2008), "A framework of sustainable supply chain management: moving toward new theory", International journal of physical distribution and logistics management, Vol. 38 No. 5, pp. 360-387.

Castaldo, S., Perrini, F., Misani, N., and Tencati, A. (2009), "The missing link between corporate social responsibility and consumer trust: The case of fair trade products", Journal of business ethics, Vol. 84 No. 1, pp. 1-15.

Ciliberti, F., de Groot, G., de Haan, J., and Pontrandolfo, P. (2009), "Codes to coordinate supply chains: SMEs' experiences with SA8000", Supply Chain Management: An International Journal, Vol. 14 No. 2, pp. 117-127.

Closs, D. J., Speier, C., and Meacham, N. (2011), "Sustainability to support end-to-end value chains: the role of supply chain management", Journal of the Academy of Marketing Science, Vol. 39 No. 1, pp. 101-116.

Coombs, W. T. (2014), “Ongoing crisis communication: Planning, managing, and responding”, Sage Publications, Thousand Oaks, CA, USA.

Cousins, P. D. (2005), "The alignment of appropriate firm and supply strategies for competitive advantage", International Journal of Operations and Production Management, Vol. 25 No. 5, pp. 403-428.

Cruz, L.B., and Boehe, D. M. (2008), "CSR in the global marketplace: Towards sustainable global value chains", Management Decision, Vol. 46 No. 8, pp. 1187-1209.

Donaldson, T., and Preston, L. E. (1995), "The stakeholder theory of the corporation: Concepts, evidence, and implications", Academy of management Review, Vol. 20 No. 1, pp. 65-91.

Egels-Zandén, N. (2007), “Suppliers’ compliance with MNCs' codes of conduct: Behind the scenes at Chinese toy suppliers", Journal of Business Ethics, Vol. 75 No. 1, pp. 45-62.

Ewing, M. T., Windisch, L., and Newton, F. J. (2010), "Corporate reputation in the People's Republic of China: A B2B perspective", Industrial Marketing Management, Vol. 39 No. 5, pp. 728-736. 
Fan, Y. (2005), "Ethical branding and corporate reputation", Corporate communications: An international journal, Vol. 10 No. 4, pp. 341-350.

Fawcett, S. E., and Magnan, G. M. (2002), "The rhetoric and reality of supply chain integration", International Journal of Physical Distribution and Logistics Management, Vol. 32 No. 5, pp. 339-361.

Fearne, A., Duffy, R., and Hornibrook, S. (2005), "Justice in UK supermarket buyersupplier relationships: an empirical analysis", International Journal of Retail and Distribution Management, Vol. 33 No. 8, pp. 570-582.

Ferguson, T. D., Deephouse, D. L., and Ferguson, W. L. (2000), "Do strategic groups differ in reputation?” Strategic Management Journal, Vol. 21 No. 12, pp. 1195-1214.

Flanagan, D. J., O'Shaughnessy, K. C., and Palmer, T. B. (2011), "Re-assessing the relationship between the fortune reputation data and financial performance: Overwhelming influence or just a part of the puzzle?" Corporate Reputation Review, Vol. 14 No. 1, pp. 3-14.

Fombrun, C., and Shanley, M. (1990), "What's in a name? Reputation building and corporate strategy", Academy of management Journal, Vol. 33 No. 2, pp. 233-258.

Fombrun, C. J., Gardberg, N. A., and Sever, J. M. (2000), “The Reputation QuotientSM: A multi-stakeholder measure of corporate reputation", Journal of Brand Management, Vol. 7 No. 4, pp. 241-255.

Freeman, R. E., and Reed, D. L. (1983), "Stockholders and stakeholders: A new perspective on corporate governance", California management review, Vol. 25 No. 3, pp. 88106.

Freeman, R. E. (1999), “Divergent stakeholder theory”, Academy of management review, Vol. 24 No. 2, pp. 233-236.

Galbraith, C., and Schendel, D. (1983), "An empirical analysis of strategy types", Strategic Management Journal, Vol. 4 No. 2, pp. 153-173.

Gold, S., Seuring, S., and Beske, P. (2010), "Sustainable supply chain management and inter-organizational resources: a literature review", Corporate social responsibility and environmental management, Vol. 17 No. 4, pp. 230-245. 
Gold, S. and Heikkurinen, P. (2013), "Corporate responsibility, supply chain management and strategy: In search of new perspectives for sustainable food production", Journal of Global Responsibility, Vol. 4 No. 2, pp.276-291.

Gonzalez-Benito, J. (2007), "A theory of purchasing's contribution to business performance", Journal of Operations Management, Vol. 25 No. 4, pp. 901-917.

Govindan, K., Kaliyan, M., Kannan, D., and Haq, A. N. (2014), "Barriers analysis for green supply chain management implementation in Indian industries using analytic hierarchy process", International Journal of Production Economics, Vol. 147, pp. 555-568.

Gray, E. R., and Balmer, J. M. (1998), "Managing corporate image and corporate reputation", Long range planning, Vol. 31 No. 5, pp. 695-702.

Greyser, S. A. (1999), “Advancing and enhancing corporate reputation", Corporate Communications: An International Journal, Vol. 4 No. 4, pp. 177-181.

Gugler, P., and Shi, J. Y. (2009), “Corporate social responsibility for developing country multinational corporations: lost war in pertaining global competitiveness?", Journal of Business Ethics, Vol. 87 No. 1, pp. 3-24.

Harwood, I., and Humby, S. (2008), "Embedding corporate responsibility into supply: A snapshot of progress”, European Management Journal, Vol. 26 No. 3, pp. 166-174.

Helm, S., and Salminen, R. T. (2010), "Basking in reflected glory: Using customer reference relationships to build reputation in industrial markets", Industrial Marketing Management, Vol. 39 No. 5, pp. 737-743.

Hemphill, T. A. and Kelley, K. J. (2016), "Socially responsible global supply chains: The human rights promise of shared responsibility and ISO 45001", Journal of Global Responsibility, Vol. 7 No. 2, pp. 163-180.

Herbig, P., Milewicz, J., and Golden, J. (1994), "A model of reputation building and destruction”, Journal of Business Research, Vol. 31 No. 1, pp. 23-31.

Hoejmose, S., Brammer, S., and Millington, A. (2013), "An empirical examination of the relationship between business strategy and socially responsible supply chain management", International Journal of Operations and Production Management, Vol. 33 No. 5, pp. 589621. 
Hoejmose, S. U., Roehrich, J. K., and Grosvold, J. (2014), "Is doing more doing better? The relationship between responsible supply chain management and corporate reputation", Industrial Marketing Management, Vol. 43 No. 1, pp. 77-90.

Howard-Grenville, J. A., and Hoffman, A. J. (2003), "The importance of cultural framing to the success of social initiatives in business", The Academy of Management Executive, Vol. 17 No. 2, pp. 70-84.

Husted, B. W., and Allen, D. B. (2001), "Toward a model of corporate social strategy formulation", In Proceedings of the Social Issues in Management Division at Academy of Management Conference (pp. 1-35),

Husted, B. W., and Allen, D. B. (2007), "Corporate social strategy in multinational enterprises: Antecedents and value creation", Journal of Business Ethics, Vol. 74 No. 4, pp. 345-361.

Jones, B., Temperley, J., and Anderson, L. (2009), "Corporate reputation in the era of Web 2.0: the case of Primark", Journal of Marketing Management, Vol. 25 Nos. 9-10, pp. 927-939.

Keh, H. T., and Xie, Y. (2009), "Corporate reputation and customer behavioral intentions: The roles of trust, identification and commitment", Industrial Marketing Management, Vol. 38 No. 7, pp. 732-742.

Klassen, R. D., and Vereecke, A. (2012), "Social issues in supply chains: Capabilities link responsibility, risk (opportunity), and performance", International Journal of Production Economics, Vol. 140 No. 1, pp. 103-115.

Kleindorfer, P. R., Singhal, K., and Wassenhove, L. N. (2005), "Sustainable operations management", Production and operations management, Vol. 14 No. 4, pp. 482-492.

Knudsen, D. (2003), "Aligning corporate strategy, procurement strategy and eprocurement tools", International Journal of Physical Distribution and Logistics Management, Vol. 33 No. 8, pp. 720-734.

Lai, C. S., Chiu, C. J., Yang, C. F., and Pai, D. C. (2010), "The effects of corporate social responsibility on brand performance: The mediating effect of industrial brand equity and corporate reputation", Journal of business ethics, Vol. 95 No. 3, pp. 457-469. 
Lantos, G. P. (2001), "The boundaries of strategic corporate social responsibility", Journal of consumer marketing, Vol. 18 No. 7, pp. 595-632.

Lee, K. H., and Kim, J. W. (2009), "Current status of CSR in the realm of supply management: the case of the Korean electronics industry", Supply Chain Management: An International Journal, Vol. 14 No. 2, pp. 138-148.

Lefevre, C., Pellé, D., Abedi, S., Martinez, R., and Thaler, P. F. (2010), "Value of sustainable procurement practices", Collaborative report from PwC, EcoVadis and INSEAD.

Lim, S. J., and Phillips, J. (2008), "Embedding CSR values: The global footwear industry's evolving governance structure", Journal of Business Ethics, Vol. 81 No. 1, pp. 143-156.

Liu, S., Kasturiratne, D., and Moizer, J. (2012), "A hub-and-spoke model for multidimensional integration of green marketing and sustainable supply chain management", Industrial Marketing Management, Vol. 41 No. 4, pp. 581-588.

Maignan, I., Ferrell, O. C., and Ferrell, L. (2005), "A stakeholder model for implementing social responsibility in marketing", European Journal of Marketing, Vol. 39 Nos. 9/10, pp. 956-977.

Markley, M. J., and Davis, L. (2007), "Exploring future competitive advantage through sustainable supply chains", International Journal of Physical Distribution and Logistics Management, Vol. 37 No. 9, pp. 763-774.

McElhaney, K. (2009), “A strategic approach to corporate social responsibility”, Leader to Leader, Vol. 52 No. 1, pp. 30-36.

McManus, T. (2008), “The business strategy/corporate social responsibility mash-up", Journal of Management Development, Vol. 27 No. 10, pp. 1066-1085.

McWilliams, A., and Siegel, D. (2001), "Corporate social responsibility: A theory of the firm perspective", Academy of management review, Vol. 26 No. 1, pp. 117-127.

McWilliams, A., Siegel, D. S., and Wright, P. M. (2006), "Corporate social responsibility: Strategic implications", Journal of management studies, Vol. 43 No. 1, pp. 118. 
Miller, D., and Toulouse, J. M. (1986), "Chief executive personality and corporate strategy and structure in small firms", Management science, Vol. 32 No. 11, pp. 1389-1409.

Mohr, J., and Spekman, R. (1994), "Characteristics of partnership success: partnership attributes, communication behavior, and conflict resolution techniques", Strategic management journal, Vol. 15 No. 2, pp. 135-152.

Mohr, L. A., and Webb, D. J. (2005), "The effects of corporate social responsibility and price on consumer responses", Journal of Consumer Affairs, Vol. 39 No. 1, pp. 121-147.

Monczka, R. M., Handfield, R. B., Giunipero, L. C., and Patterson, J. L. (2015), "Purchasing and supply chain management”. Cengage Learning. Mason (OH) USA.

Money, K., Hillenbrand, C., and Downing, S. (2011), "Reputation in relationships". In Reputation Management (pp. 75-88), Springer Berlin Heidelberg.

Mulgan, G., Tucker, S., Ali, R., and Sanders, B. (2007), "Social innovation: what it is, why it matters and how it can be accelerated", Said Business School, University of Oxford Working Paper. http://eureka.sbs.ox.ac.uk/761/1/Social_Innovation.pdf.

Narasimhan, R., and Carter, J. R. (1998), "Linking business unit and material sourcing strategies", Journal of business Logistics, Vol. 19 No. 2, pp. 155-171.

Orlitzky, M., Schmidt, F. L., and Rynes, S. L. (2003), "Corporate social and financial performance: A meta-analysis”, Organization studies, Vol. 24 No. 3, pp. 403-441.

Palazzo, G., and Basu, K. (2007), “The ethical backlash of corporate branding”, Journal of Business Ethics, Vol. 73 No. 4, pp. 333-346.

Park, H., and Dickson, M. A. (2008), "Engaging in Buyer-Seller Partnership for Fair Labor Management The Role of a Buyer Firm's Strategic Emphasis", Clothing and textiles research journal, Vol. 26 No. 1, pp. 41-56.

Park-Poaps, H., and Rees, K. (2010), "Stakeholder forces of socially responsible supply chain management orientation", Journal of Business Ethics, Vol. 92 No. 2, pp. 305-322.

Pedersen, E.R. (2009), “The many and the few: rounding up the SMEs that manage CSR in the supply chain", Supply Chain Management: An International Journal, Vol. 14 No. 2, pp. 109-116. 
Phillips, R., and Caldwell, C. B. (2005), "Value chain responsibility: A farewell to arm's length”, Business and Society Review, Vol. 110 No. 4, pp. 345-370.

Pickles, J., and Zhu, S. (2013), "The California Transparency in Supply Chains Act", http://papers.ssrn.com/sol3/papers.cfm?abstract_id=2237437.

Piercy, N. F., and Lane, N. (2009), "Corporate social responsibility: impacts on strategic marketing and customer value", The Marketing Review, Vol. 9 No. 4, pp. 335-360.

Ponzi, L. J., Fombrun, C. J., and Gardberg, N. A. (2011), "RepTrak"TM pulse: Conceptualizing and validating a short-form measure of corporate reputation”, Corporate Reputation Review, Vol. 14 No. 1, pp. 15-35.

Porter, M. E. (1986), "Competition in global industries", Harvard Business Press. Boston, USA.

Porter, M. E., and Kramer, M. R. (2006), "Strategy and society: the link between corporate social responsibility and competitive advantage", Harvard business review, Vol. 84 Nos. 1/2, pp. 78-92.

Power, D. (2005), "Supply chain management integration and implementation: a literature review", Supply chain management: an International journal, Vol. 10 No. 4, pp. $252-263$

Preuss, L. (2001), "In dirty chains? Purchasing and greener manufacturing", Journal of Business Ethics, Vol. 34 Nos. 3-4, pp. 345-359.

Preuss, L. (2009), “Addressing sustainable development through public procurement: the case of local government", Supply Chain Management: An International Journal, Vol. 14 No. 3, pp. 213-223.

Roberts, S. (2003), "Supply chain specific? Understanding the patchy success of ethical sourcing initiatives", Journal of business ethics, Vol. 44 Nos. 2-3, pp. 159-170.

Russo, A., and Perrini, F. (2010), "Investigating stakeholder theory and social capital: CSR in large firms and SMEs”, Journal of Business ethics, Vol. 91 No. 2, pp. 207-221. 
Sarkis, J., Zhu, Q., and Lai, K. H. (2011), “An organizational theoretic review of green supply chain management literature", International Journal of Production Economics, Vol. 130 No. 1 , pp. 1-15.

Seuring, S., and Müller, M. (2008), "From a literature review to a conceptual framework for sustainable supply chain management", Journal of cleaner production, Vol. 16 No. 15, pp. 1699-1710.

Sharma, A., Iyer, G. R., Mehrotra, A., and Krishnan, R. (2010), "Sustainability and business-to-business marketing: A framework and implications", Industrial Marketing Management, Vol. 39 No. 2, pp. 330-341.

Siegel, D. S., and Vitaliano, D. F. (2007), "An empirical analysis of the strategic use of corporate social responsibility", Journal of Economics and Management Strategy, Vol. 16 No. 3, pp. 773-792.

Siltaoja, M. E. (2006), "Value priorities as combining core factors between CSR and reputation-a qualitative study", Journal of Business Ethics, Vol. 68 No. 1, pp. 91-111.

Simpson, D., Power, D., and Samson, D. (2007), "Greening the automotive supply chain: a relationship perspective", International Journal of Operations and Production Management, Vol. 27 No. 1, pp. 28-48.

Surroca, J., Tribó, J. A., and Waddock, S. (2010), “Corporate responsibility and financial performance: The role of intangible resources", Strategic Management Journal, Vol. 31 No. 5, pp. 463-490.

Tamas, M. (2000), “Mismatched strategies: the weak link in the supply chain?”, Supply Chain Management: An International Journal, Vol. 5 No. 4, pp. 171-175.

Tate, W. L., Ellram, L. M., and Kirchoff, J. F. (2010), "Corporate social responsibility reports: a thematic analysis related to supply chain management", Journal of supply chain management, Vol. 46 No. 1, pp. 19-44.

Tetrault Sirsly, C. A., Lamertz, K.(2008), “When Does a Corporate Social Responsibility Initiative Provide a First-Mover Advantage”, pp. 343-369.

Van de Ven, B., and Jeurissen, R. (2005), "Competing responsibly", Business Ethics Quarterly, Vol. 15 No. 2), pp. 299-317. 
Walker, H., Di Sisto, L., and McBain, D. (2008), "Drivers and barriers to environmental supply chain management practices: Lessons from the public and private sectors", Journal of purchasing and supply management, Vol. 14 No. 1, pp. 69-85.

Walker, H., and Preuss, L. (2008), "Fostering sustainability through sourcing from small businesses: public sector perspectives", Journal of Cleaner Production, Vol. 16 No. 15, pp. 1600-1609.

Walker, H., and Jones, N. (2012), "Sustainable supply chain management across the UK private sector", Supply Chain Management: An International Journal, Vol. 17 No. 1, pp. 1528.

Watts, C. A., Kim, K. Y., and Hahn, C. K. (1995), "Linking purchasing to corporate competitive strategy", Journal of Supply Chain Management, Vol. 31 No., 2, pp. 2.

Weigelt, K., and Camerer, C. (1988), "Reputation and corporate strategy: A review of recent theory and applications", Strategic management journal, Vol. 9 No. 5, pp. 443-454.

Weitzner, D., and Darroch, J. (2010), "The limits of strategic rationality: Ethics, enterprise risk management, and governance", Journal of Business Ethics, Vol. 92 No. 3, pp. 361-372.

Winstanley, D., Clark, J., and Leeson, H. (2002), “Approaches to child labour in the supply chain", Business Ethics: A European Review, Vol. 11 No. 3, pp. 210-223.

Xia, Y., Zu, X., and Shi, C. (2015), “A profit-driven approach to building a "peopleresponsible" supply chain", European Journal of Operational Research, Vol. 241 No. 2, pp. 348-360.

Yawar, S. A., and Seuring, S. (2015), "Management of social issues in supply chains: a literature review exploring social issues, actions and performance outcomes", Journal of Business Ethics, pp. 1-23.

$\mathrm{Yu}, \mathrm{X}$. (2008), "Impacts of corporate code of conduct on labor standards: A case study of Reebok's athletic footwear supplier factory in China”, Journal of Business Ethics, Vol. 81 No. 3, pp. 513-529. 
Zhu, Q., Sarkis, J., and Lai, K. H. (2013), "Institutional-based antecedents and performance outcomes of internal and external green supply chain management practices", Journal of Purchasing and Supply Management, Vol. 19 No. 2, pp. 106-117. 